\title{
Rozwój przemysłu oraz usług na terenie Jelcza-Laskowic jako czynnik rozwoju społeczeństwa informacyjnego w mieście
}

\author{
CZYNNIKI ROZWOJU SPOŁECZEŃSTWA INFORMACYJNEGO \\ W JELCZU-LASKOWICACH
}

Za społeczeństwo informacyjne uważane jest społeczeństwo, w którym przetwarzanie informacji z wykorzystaniem technologii informacyjnych i komunikacyjnych stanowi znaczną wartość ekonomiczna, społeczną i kulturową. Definicja ta odnosi się również do społeczności Jelcza-Laskowic. Gwałtowny wzrost znaczenia informacji świadczonych drogą elektroniczną oraz wykorzystanie technologii komunikacyjnych i informacyjnych w pracy, życiu codziennym czy publicznym spowodowało transformację społeczeństwa Jelcza-Laskowic i zmianę ze społeczeństwa przemysłowego w kierunku społeczeństwa informacyjnego. Zmiana ta stanowi bardzo ważny element zapewniający szybki i zrównoważony rozwój społeczno-gospodarczy nie tylko samego miasta, ale również systemu osadniczo-produkcyjnego, który to miasto tworzy (czyli Jelcz-Laskowice oraz 14 okolicznych miejscowości). Efektem tego przekształcenia jest poprawa warunków życia i podniesienie stopy życiowej obywateli (Strategia rozwoju... 2006, s. 4).

Wyróżnić można szereg czynników, które wpływają na kształtowanie się i rozwój społeczeństwa informacyjnego w Jelczu-Laskowicach. Do najważniejszych zaliczyć można: rozwój sektora przemysłu, głównie motoryzacyjnego, i usług na terenie miasta, technologie informacyjne i komunikacyjne (ICT) oraz umiejętność mieszkańców posługiwania się nimi, dostęp do Internetu, nowoczesne kwalifikacje pracowników, odpowiadające wymogom pracodawców, nowe formy zatrudnienia (telepraca) oraz nowe kierunki kształcenia.

Ważną rolę odgrywa przemysł i usługi, ponieważ jest to główny „motor” podtrzymujący funkcjonowanie miasta, którego podstawą istnienia są zakłady przemysłowe. Stał się on genezą powstania, kształtowania się, a następnie rozwoju społeczeństwa informacyjnego w mieście.

W momencie rozpoczęcia funkcjonowania Jelczańskiej Podstrefy Ekonomicznej oraz obecnie do miasta napływa szereg inwestycji zagranicznych, głównie w przemysł motoryzacyjny. W latach 2003-2008 było to przyczyną znacznego przyspieszenia działań unowocześniania procesów produkcyjnych, na które nałożyły się przeobrażenia strukturalne oraz wpro- 
wadzenie i rozwój nowych technologii produkcji. Spowodowało to ogromną modernizację sektora motoryzacji, który nie istniałby bez nowych zakładów produkcyjnych. Stosując zasadę: NOWOCZESNA PRODUKCJA + TECHNOLOGIE ICT = KONKURENCYJNOŚC + ZATRUDNIENIE przemysł stał się głównym czynnikiem warunkującym rozwój miasta i jego społeczności. Rozwój nowoczesnych linii produkcyjnych z automatyzacją i robotyzacją stał się głównym powodem napływu nowoczesnych technologii. Spowodowało to konieczność zdobywania przez pracowników nowych kwalifikacji dostosowanych do wymogów rynkowych. Zmiany w zakresie produkcji, stosowanych technologii spowodowały zapotrzebowanie na nowe zawody, np. z dziedziny technologii informacyjnych i komunikacyjnych, marketingu, bankowości, a także nowe umiejętności, takie jak: obsługa komputera, obsługa robota. Nadzwyczaj ważne stały się nowoczesne i skuteczne systemy edukacji i szkoleń oferowane przez firmy zagraniczne w zakresie podnoszenia umiejętności ICT w celu prawidłowej obsługi urządzeń. Miały one ogromne znaczenie na wielu płaszczyznach, poczynając od konkurencyjności firm na rynku krajowym czy europejskim, a kończąc na integracji społecznej. Tego typu szkolenia nie odbyłyby się bez technologii informatycznych i komunikacyjnych, które umożliwiły ludziom w różnym wieku naukę opartą na elastycznych metodach. Aby jednak pracownicy mogli korzystać z nowych możliwości i wchodzić w nurt społeczeństwa informacyjnego, konieczne jest szerzenie umiejętności informatycznych, bez których nie mogą wykonywać swoich obowiązków w pracy.

Konkurencyjność przemysłu, a tym samym gospodarki lokalnej, w dużym stopniu zależy właśnie od poziomu wiedzy społeczeństwa oraz od umiejętności tworzenia i wykorzystywania wiedzy technicznej, informatycznej i ekonomicznej. Wysoko wykształcone i posiadające wysokie umiejętności praktyczne zasoby ludzkie są niezbędnym warunkiem postępu technicznego, gospodarczego i społecznego.

Istnienie nowoczesnych firm w sektorze przemysłu w Jelczu-Laskowicach niejako wymusza rozwój społeczeństwa informacyjnego. Nowoczesne techniki produkcji i technologie ICT dają zupełnie nowe możliwości, których wcześniej nie było. Sektor przemysłu rozwinął w mieście nowe horyzonty życia społeczno-gospodarczego.

Zmianie uległy również formy pracy w samym zakładzie oraz wśród pracowników. Firmy sięgając po ICT łączą swoje procesy i systemy biznesowe. Wewnątrz zakładów następuje łączenie działów w celu podnoszenia jakości produktów i świadczenia usług dostosowanych do indywidualnych potrzeb odbiorców w bardziej wydajny sposób.

Następuje konsolidowanie się z urzędami państwowymi oraz gminy, co umożliwia ograniczenie formalności, szybsze załatwianie spraw, płynny przepływ informacji. Z kolei łączenie procesów produkcyjnych firm przemysłowych z procesami i systemami dostawców, dystrybutorów czy klientów umożliwia szybkie i bezpośrednie reagowanie na tendencje rynkowe.

Tworzone są również nowe miejsca pracy dla tzw. ruchomego społeczeństwa. Można spotkać się z wykonywaniem telepracy w każdym zakładzie przez kilku lub kilkunastu pracowników. Jest to nowa forma zatrudnienia, która wcześniej na terenie miasta nie była praktykowana. Wprowadzanie tego typu formy pracy ma wymierne korzyści dla społeczeństwa, takie jak obniżenie poziomu zanieczyszczenia środowiska, natężenia ruchu pojazdów oraz spadek konsumpcji energii. Elastyczne warunki pracy są szczególnie korzystne dla wszystkich dojeżdżających dotąd do pracy z odległych miejsc zamieszkania.

Zakłady przemysłowe z kapitałem zagranicznym są dynamiczne i elastyczne, o ogromnym potencjale wzrostu gospodarczego. Dzięki temu zapoczątkowały prowadzenie w Jelczu- 
Laskowicach biznesu elektronicznego. Wskazało to firmom istniejącym nowe formy komunikacji, partnerstwa, a także prowadzenia interesów oraz oferowania nowej jakości usług i produktów. Stało się szczególnie atrakcyjną formą prowadzenia działalności, gdyż e-biznes umożliwił korzystanie z możliwości, jakie oferuje wspólny rynek.

Ważnym czynnikiem w kształtowaniu się społeczeństwa informacyjnego w mieście jest rozwijający się sektor usług nowoczesnych (bankowość, finanse, telekomunikacja, informatyka oraz zarządzanie). Wśród podmiotów prowadzących działalności usługowe dominującą rolę odgrywają przedsiębiorstwa handlowe (wg PKD sekcja G).

\section{OD SPOŁECZEŃSTWA PRZEMYSŁOWEGO DO SPOŁECZEŃSTWA INFORMACYJNEGO}

Nieodłącznym elementem, który stymulował różnego rodzaju zmiany, jakie dokonywały się w koncepcjach organizowania pracy, był szeroko rozumiany postęp technologiczny. Dzięki niemu nastąpiło w obrębie badanego miasta przejście od społeczeństwa przemysłowego do społeczeństwa informacyjnego. Spowodowało to także restrukturyzację jelczańskiego przemysłu, a w konsekwencji wywołało zmiany w życiu lokalnego społeczeństwa. Istnienie społeczeństwa przemysłowego w Jelczu-Laskowicach można wyznaczyć na lata 50. do końca XX w., czyli na okres intensywnego rozwoju przemysłu motoryzacyjnego (głównie w Jelczańskich Zakładach Samochodowych). Początek XXI w. to czas kryzysu tego sektora produkcji i jego restrukturyzacji.

Dynamiczny rozwój przemysłu związany był z opanowaniem produkcji masowej, dystrybucji towarów i kontrolowania rynku konsumpcji dóbr i usług. Jednakże jego gwałtowny rozwój spowodował kryzys w zakresie produkcji. Odpowiedzią na owe niedomagania było pojawienie się „,rewolucji” telekomunikacyjnej, która miała usprawnić te procesy, a ta z kolei stała się podstawą do rozwoju społeczeństwa informacyjnego (Globan-Klas 1999, s. 288-289).

Rozwój technologii informatyczno-telekomunikacyjnych uruchomił proces rozwoju informatyzacji, dzięki któremu tradycyjne społeczeństwo przemysłowe uległo transformacji. Efektem dokonujących się przeobrażeń było powstanie społeczeństwa informacyjnego.

Społeczeństwo przemysłowe dokonywało przeobrażeń w sferze działalności produkcyjnej - zmiany dokonywały się przy taśmach, w halach produkcyjnych. Technika powstająca w jej wyniku była dość prosta i rzadko opierała się na dokonaniach naukowych. Natomiast społeczeństwo informacyjne prace wykonuje w centrach naukowo-badawczych, biurach projektowych, a dopiero jej efekt końcowy wpływa na transformacje w sferze produkcyjnej. Zmiany dokonują się w sferze koncepcyjnej produktu, a dopiero w późniejszej fazie w sferze produkcyjnej.

W społeczeństwie przemysłowym nowe technologie i wynalazki zastępowały pracę fizyczną człowieka. Obecnie nowa fala postępujących zmian technologicznych nie poprzestaje na przeobrażeniach fizycznych aspektów pracy, ale sięga nieco dalej, dokonując zmian w strukturze pojęciowej, merytorycznej wykonywanych zadań. Przemiany te powodują również zmianę podejścia do zagadnień pracy (Stroińska 2004, s. 65).

Ważny jest fakt, iż przemiany, jakie dokonują się dzięki nowoczesnym technologiom na terenie Jelcza-Laskowic, łączą technologię informatyczna, telekomunikacyjną oraz eko- 
nomię. Dzięki tym trzem sektorom następują zmiany w sferze gospodarczej oraz społecznej i kulturowej mieszkańców. Życie mieszkańców uległo przeobrażeniom.

Rozwój społeczeństwa informacyjnego to również kształtowanie aktywnych postaw społecznych. Jest ono świadome swoich możliwości, gotowe do podejmowania wszelkich wyzwań, ale także odpowiedzialne za zachodzące zmiany w skali mikro.

Społeczeństwo informacyjne w porównaniu do społeczeństwa przemysłowego charakteryzuje się odmiennym podejściem do aktywności społecznej. Sektor informatyczny prześcignął sektor przemysłowy, i to właśnie spowodowało zmianę społeczeństwa badanego miasta. Podstawą przemian społecznych stały się wiedza i informacje, a nie - jak w przypadku społeczeństwa przemysłowego - kapitał i praca.

Należy jednak podkreślić ważny fakt, iż w dobie społeczeństwa przemysłowego nastąpił znaczny rozwój poszczególnych części „miasta zlepieńca”, czyli przemysłowego Jelcza i utworzonej dla jego pracowników „sypialni” - Laskowic. Dzięki temu efektem w dobie społeczeństwa informacyjnego było połączenie tych części i utworzenie miasta.

\section{CharAKTERYSTYKA SPOŁECZEŃSTWA INFORMACYJNEGo JELCZA-LASKOWIC}

Pojęcie społeczeństwa informacyjnego odnoszące się do mieszkańców Jelcza-Laskowic podkreśla fakt, iż szerokie zastosowanie infrastruktury informatycznej ma ogromne znaczenie dla funkcjonowania tej społeczności. Oznacza to dostęp do informacji, możliwość swobodnego (interaktywnego) dostępu do danych i ich wymiany, możliwość dokonywania rozmaitych transakcji na odległość, połączenia się i komunikowania w dowolnej chwili z dowolnie wybranego miejsca, czy oferowanie usług, dostępu do rozrywki w zależności od indywidualnych zainteresowań i potrzeb. Tak więc cechą charakteryzującą społeczeństwo informacyjne Jelcza-Laskowic jest aktywne stosowanie technologii informacyjnej w życiu codziennym zarówno w miejscu pracy, jak i w życiu osobistym.

Badając, czy społeczność Jelcza-Laskowic jest społeczeństwem informacyjnym, posłużyłam się wybranymi wskaźnikami oraz ich analizą. Badanie wykorzystania technologii informacyjno-telekomunikacyjnych $\mathrm{w}$ gospodarstwach domowych i przez użytkowników indywidualnych (w wieku 16-74 lat) obejmuje lata 2004, 2006, 2008. Badania koncentrowały się głównie na kwestiach dostępu oraz sposobach i celach wykorzystania tychże technologii. Rozważania oparte są na podstawie badań reprezentacyjnych (zbadana została niewielka część populacji, a wyniki uogólnione na całość populacji).

Ważną cechą charakteryzującą społeczeństwo informacyjne Jelcza-Laskowic jest ścisła integracja z informacją. Przejawia się to poprzez wykorzystanie narzędzi informatycznych do magazynowania, przekształcania, tworzenia informacji oraz do komunikacji między członkami społeczeństwa. Ważnym wyróżnikiem jest również wysoki poziom wykształconych jednostek wśród jego członków oraz wysoki wskaźnik osób uczących się w stosunku do całej liczebności populacji. Tak więc istotną rolę w tworzeniu się społeczeństwa informacyjnego odgrywa posiadanie urządzeń niezbędnych do przekazywania i przetwarzania informacji, tj. telefonów i komputerów (ryc. 1). 


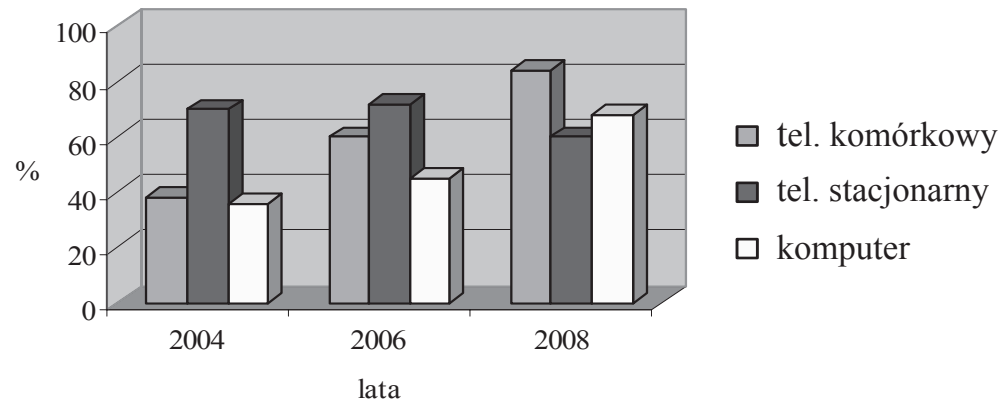

Ryc. 1. Odsetek gospodarstw domowych wyposażonych w telefony oraz komputery w latach 2006-2008 w Jelczu-Laskowicach

a) wiek

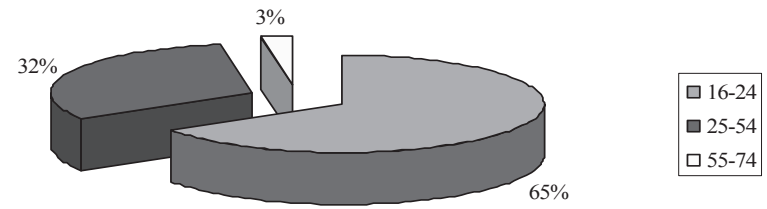

b) wykształcenie

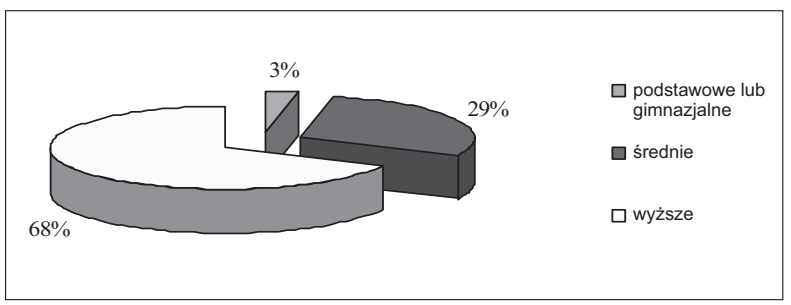

c) aktywność zawodowa

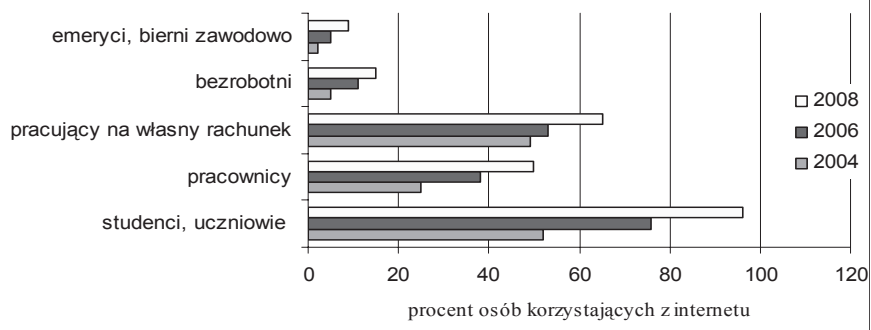

Ryc. 2. Osoby regularnie korzystające $\mathrm{z}$ komputera według wieku, wykształcenia i aktywności zawodowej w latach 2004-2008 w Jelczu-Laskowicach

Źródło: Opracowanie własne na podstawie badań ankietowych 
W badanym mieście telefony oraz komputery są najbardziej rozpowszechnionym urządzeniem telekomunikacyjnym i teleinformatycznym. Największy przyrost liczby telefonów komórkowych zauważa się w roku 2008. Odsetek gospodarstw domowych posiadających ten rodzaj telefonu wynosił wówczas $84 \%$, zaś telefonów stacjonarnych - $61 \%$. Telefon stacjonarny lub przynajmniej jeden telefon komórkowy posiadało $86 \%$ gospodarstw domowych, a ponad połowa (51\%) dysponowała zarówno telefonem stacjonarnym, jak i komórkowym. W okresie tym zauważalny jest również przyrost liczby telefonów komórkowych dodatkowo umożliwiających dostęp do Internetu. W 2008 r. komputery stacjonarne posiadało ok. 68\% gospodarstw domowych, laptopy $-8 \%$, a komputery podręczne, tj. palmptopy czy organizery $-0,2 \%$. Zauważalne jest, iż komputery posiadało $75 \%$ gospodarstw o wyższych dochodach, zaś tylko $18 \%$ gospodarstw o najniższych dochodach. Posiadanie komputerów oprócz dochodów związane jest również z posiadaniem dzieci (ryc. 2).

Zauważalne jest, iż największą grupę użytkowników Internetu stanowią ludzie młodzi w wieku szkolnym. Najczęściej są to uczniowie szkół gimnazjalnych, średnich oraz studenci. Biorąc pod uwagę poziom wykształcenia, najliczniejszą grupę stanowią ludzie z wyższym wykształceniem. Wyróżniają się wśród nich mieszkańcy posiadający własne, prywatne firmy oraz pracownicy firm prywatnych i państwowych (ryc. 3).

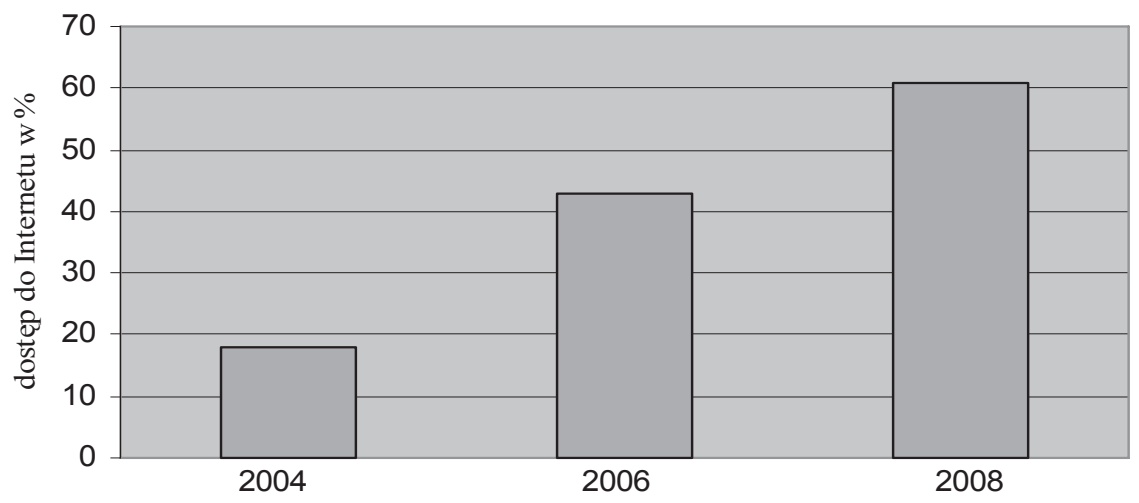

Ryc. 3. Gospodarstwa domowe z dostępem do Internetu w latach 2004-2008 w Jelczu-Laskowicach

Źródło: Opracowanie własne na podstawie badań ankietowych

Dostęp do Internetu w badanym okresie posiada coraz większa liczba użytkowników. Firmy telekomunikacyjne w mieście są operatorami infrastruktury dostępu do sieci dla dużych firm zagranicznych. Dodatkowo firmy telekomunikacyjne są otwarte na współpracę i kiedy tylko da im się możliwość dokapitalizowania przedsięwzięcia, są bardzo chętne do inwestowania, przy zaangażowaniu własnego personelu i wiedzy technicznej. Ciagły wzrost firm produkcyjnych na terenie JPE i ,zakładanie” przez nie Internetu przyczynia się w znacznym stopniu również do korzystania z Internetu przez osoby prywatne. Takie podejście powoduje, iż brak jest na terenie Jelcza-Laskowic obszarów nie objętych inwestycjami w infrastrukturę telekomunikacyjną - brak jest tzw. wykluczenia cyfrowego.

Omawiając rozwój społeczeństwa informacyjnego w mieście, należy zwrócić również uwagę na bariery, które spowalniają proces zmiany społeczeństwa przemysłowego na środowisko informacyjne. Jedną z nich jest brak nieświadomości ludzi w zakresie dostępu do 
informacji i wynikających z tego możliwości. Dotyczy to głównie ludzi starszych. Kolejną barierą jest bariera kosztowa $\mathrm{z}$ uwagi na fakt, iż dostęp do Internetu jest realizowany i oferowany przez firmy z branży telekomunikacyjnej. Pomimo jednak dobrego dostępu część mieszkańców nie korzysta z Internetu.

Problemem staje się również brak umiejętności poruszania się w sieci, niechęć, brak potrzeby itp. (ryc. 4).

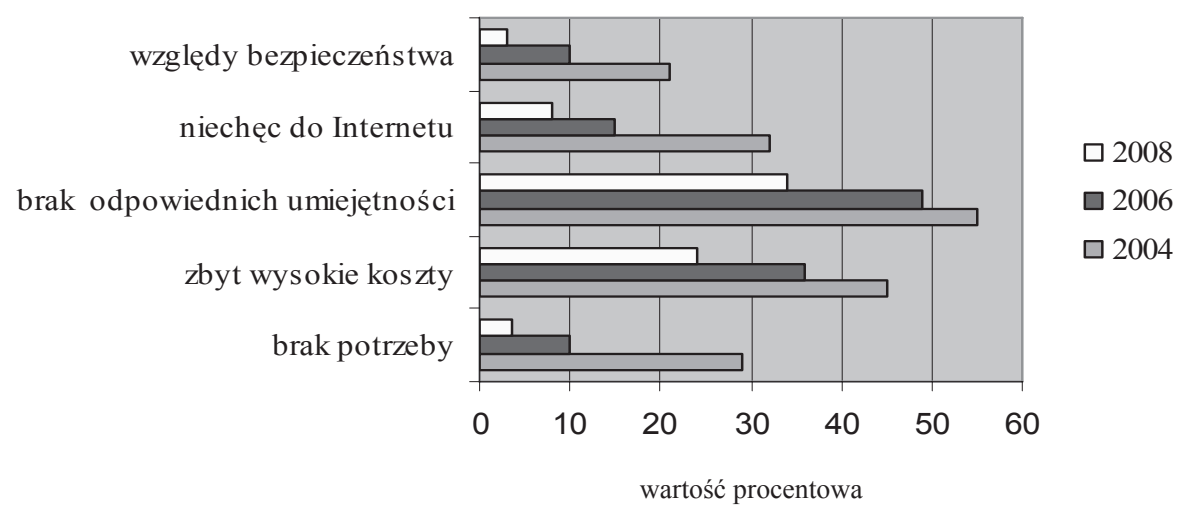

Ryc. 4. Powody braku korzystania z Internetu w Jelczu-Laskowicach w latach 2004-2008

Źródło: Opracowanie własne na podstawie badań ankietowych

Zauważalne jest jednak, że społeczeństwo Jelcza-Laskowic nadal się zmienia i w przyszłości na pewno stanie się zalążkiem w rozwoju kolejnego ogniwa ewolucyjnego. Rozwijający się nowoczesny sektor przemysłu motoryzacyjnego nie będzie miał już zapewne dużego znaczenia. Dzieje się tak, ponieważ korzyści płynące z zastosowania technologii informacyjno-telekomunikacyjnej we wszelkich aspektach życia miasta powodują powstanie efektu synergii w społeczności tegoż miasta. Oznacza to, iż korzyści płynące z funkcjonowania społeczeństwa informacyjnego są dużo większe niż środki zaangażowane w jego rozwój. Mieszkańcy rozumieją, iż zostaną wchłonięci z pożytkiem dla nich w rozwój społeczeństwa informacyjnego, co powoduje, iż starają się oni dopomóc sobie poprzez ciągłe dokształcanie się w dziedzinie informatycznej, gdyż w przyszłości każdy mieszkaniec będzie motorem napędowym w dalszym rozwoju lokalnego społeczeństwa informacyjnego.

Dokonując charakterystyki społeczeństwa informacyjnego według podanych wyżej wskaźników należałoby zwrócić uwagę na poszczególne jednostki tego społeczeństwa, czyli mieszkańców. Osoby, które można byłoby uznać za w pełni „,przynależne” do społeczeństwa informacyjnego, wyróżnia pewien zbiór umiejętności, do których oprócz ogólnej obsługi komputera zaliczyć można również biegłą obsługę Internetu. Dużo ludzi wykorzystuje w pracy komputer, coraz częściej też do realizacji praktycznych zadań w życiu prywatnym. Rośnie liczba usług i produktów dostępnych odpłatnie i nieodpłatnie przez Internet. Zwiększa się poziom wiedzy społeczeństwa z zakresu wykorzystania technik komunikacyjnych i informacyjnych w życiu prywatnym i zawodowym (ryc. 5). 


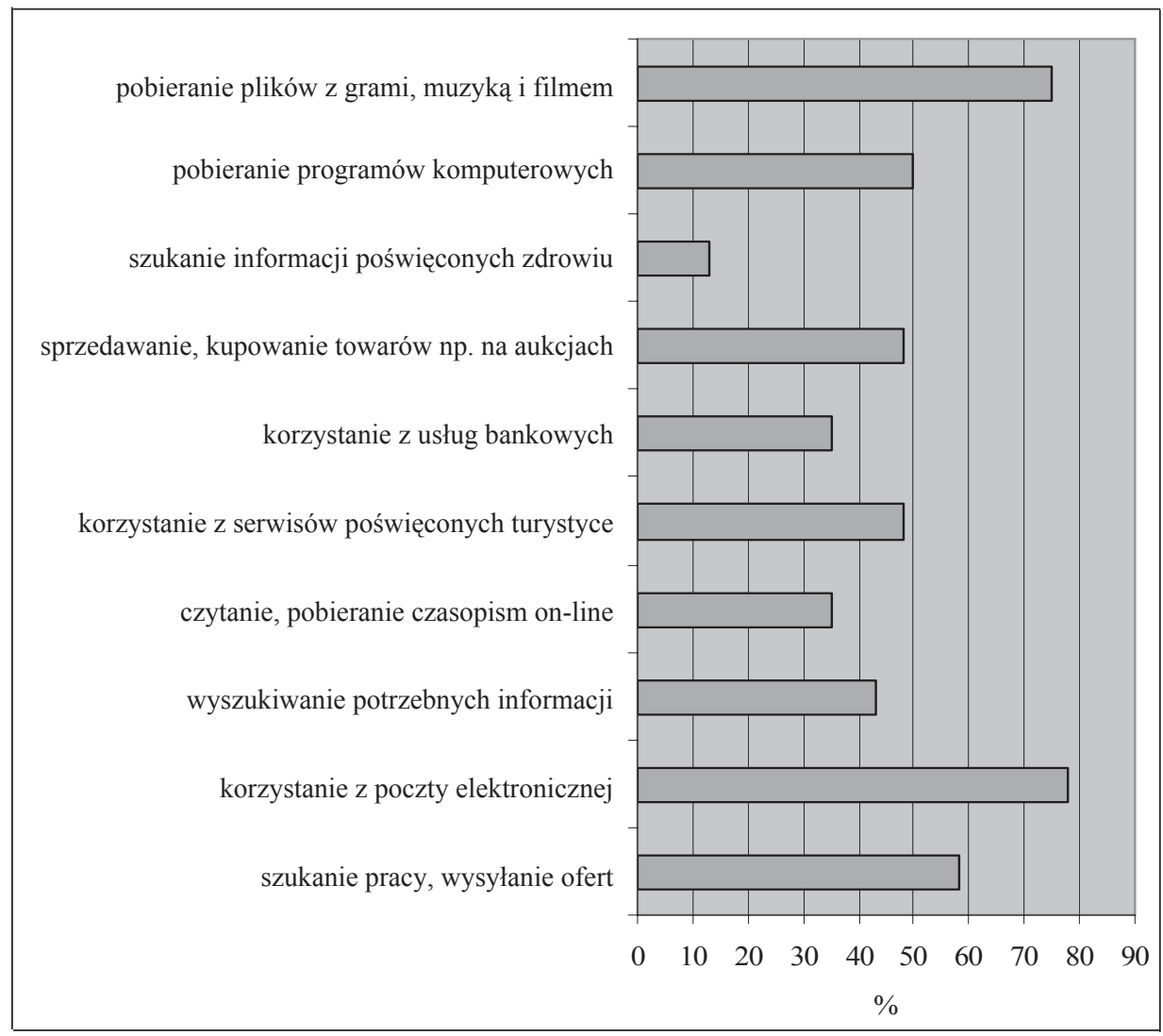

Ryc. 5. Wykorzystanie Internetu w sprawach prywatnych w $2008 \mathrm{r}$. przez mieszkańców Jelcza-Laskowic

Źródło: Opracowanie własne na podstawie badań ankietowych

Wykorzystanie Internetu do załatwiania spraw urzędowych, związanych ze zdrowiem, jest znikome, a wynika ono z faktu, iż administracja publiczna, NFZ oferuje na razie nieliczne usługi dostępne przez Internet. Zauważalne jest natomiast ogromne zainteresowanie mieszkańców świadczeniem tego typu usług. We wszystkich przypadkach liczba zainteresowanych usługami e-administracji przewyższa liczbę chcących z nich korzystać, gdyż dotyczą spraw odnoszących się do części społeczeństwa lub koniecznych do załatwienia najwyżej kilka razy w życiu. Odpowiedzi mieszkańców były przede wszystkim odbiciem ich osobistej sytuacji życiowej i związanych z nią potrzeb (ryc. 6). 


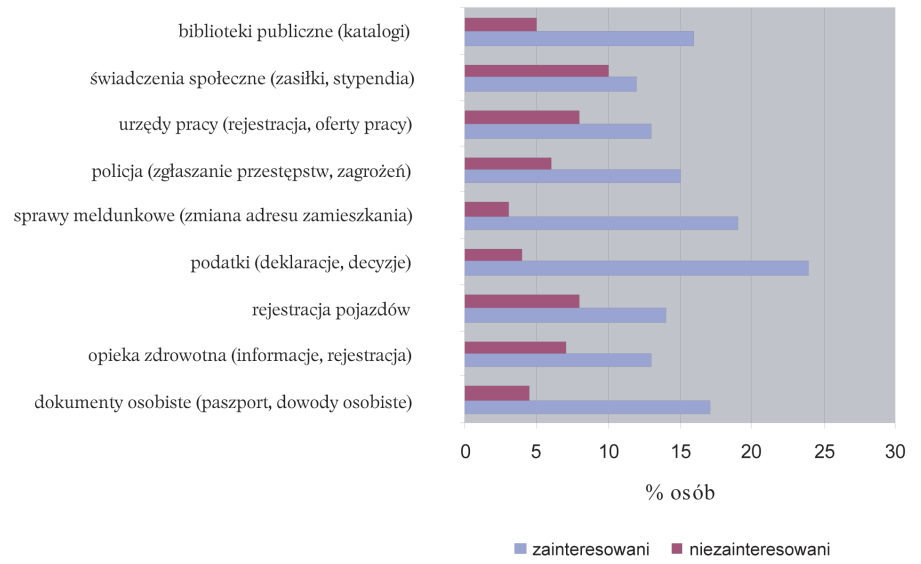

Ryc. 6. Zainteresowanie korzystaniem z usług e-administracji wśród osób w wieku 16-74 lat według rodzaju spraw w Jelczu-Laskowicach w roku 2008 r.

Źródło: Opracowanie własne na podstawie badań ankietowych

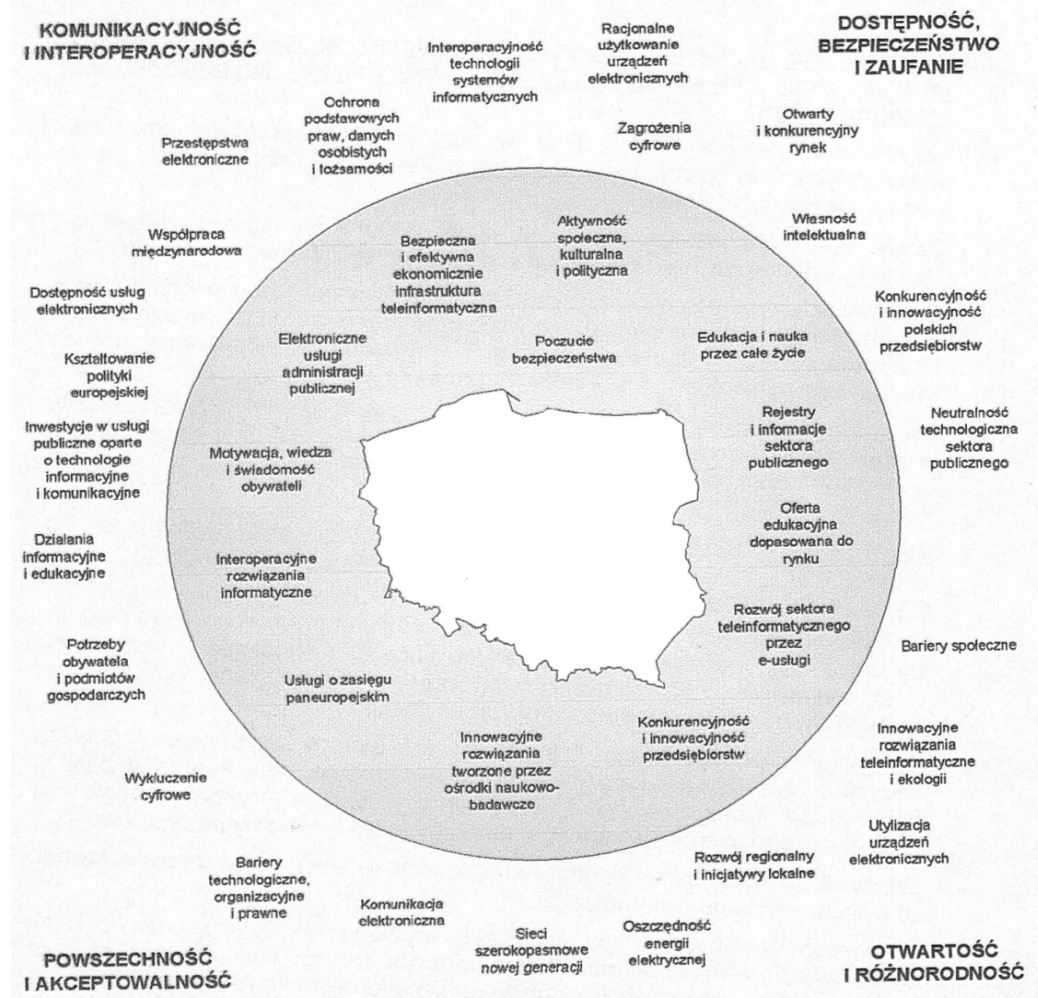

Ryc. 7. Kierunki rozwoju społeczeństwa informacyjnego Jelcza-Laskowic Źródło: Opracowanie na podstawie Strategii rozwoju... 2006 


\section{Podsumowanie}

Podsumowując można stwierdzić, iż rozwój społeczeństwa informacyjnego w JelczuLaskowicach uzależniony jest od wielu czynników wynikających z bieżących uwarunkowań i zmian zachodzących w mieście oraz jego regionie.

1. Mocne strony

Do mocnych stron umożliwiających sprawny rozwój społeczeństwa informacyjnego zaliczyć należy wysoki poziom wykształcenia kadr sektora przemysłu motoryzacyjnego, a następnie usług. Notowany jest ogólny wzrost populacji osób wykształconych w wieku produkcyjnym.

Ponadto istnieje duże zainteresowanie komercyjnymi usługami internetowymi, telefonią mobilną oraz świadczeniem pracy przez Internet. Małe i średnie przedsiębiorstwa coraz częściej wykorzystują technologie informacyjne i komunikacyjne do usprawnienia własnej działalności. Zauważa się wysoką dynamikę wzrostu sektora przemysłu motoryzacyjnego i usług, które korzystają z właściwego przygotowania infrastrukturalnego dla obrotu bezgotówkowego i e-handlu.

\section{Słabe strony}

Wśród słabych stron, mogących hamować rozwój społeczeństwa informacyjnego, wymienić można jeszcze stosunkowo niski stopień wykorzystania technologii informacyjnych i komunikacyjnych w szkolnictwie, niedostateczne powiązanie systemu edukacji z potrzebami rynku pracy oraz niski wskaźnik kształcenia ustawicznego wśród dorosłych. Ponadto wciąż istnieje w społeczeństwie grupa osób niezainteresowanych korzystaniem z technologii informacyjnych lub nieumiejących z niej korzystać.

\section{Szanse}

Szanse rozumiane są jako uwarunkowania czynników, które rokują pozytywny wpływ na stabilny rozwój społeczeństwa informacyjnego. Należy w dalszym ciąu wykorzystywać możliwości, jakie płyną z atrakcyjności inwestycyjnej miasta poprzez przyciaganie kapitału zagranicznego przy jednoczesnym transferze nowoczesnych technologii i know-how. Istotne jest upraszczanie prawa oraz usprawnianie otoczenia regulacyjnego przedsiębiorców, w tym weryfikacja prawa pod kątem wymagań rozwoju społeczeństwa informacyjnego i elektronicznej gospodarki oraz zbudowanie systemu rozwiązań legislacyjnych i finansowych, wspomagających transfer technologii do małych i średnich przedsiębiorstw. Szansą jest również konsekwentne i efektywne wykorzystanie środków finansowych, które Unia Europejska oferuje na realizację celów związanych z rozwojem społeczeństwa informacyjnego.

\section{Zagrożenia}

Zagrożenia rozumiane są jako wszelkie uwarunkowania i czynniki negatywnie wpływające na rozwój społeczeństwa informacyjnego w Jelczu-Laskowicach. Poważnym zagrożeniem jest odpływ wysoko wykształconej i doświadczonej kadry z administracji do biznesu, jak również poza granice miasta. Ryzyko stanowi także niechęć i obawa osób starszych (powyżej 60. roku życia) przed korzystaniem z nowych technologii. Rozwój społeczeństwa informacyjnego w mieście może zostać utrudniony także ze względu na obawy społeczne przed utratą prywatności w Internecie oraz koszty zapewnienia bezpieczeństwa informacji i świadczonych e-usług. 
Ponadto częsta zmiana kierunków działań strategicznych może negatywnie wpłynąć zarówno na szybkość rozwoju społeczeństwa informacyjnego, jak i koszt jego rozwoju.

Na podstawie wyżej omówionych czynników oraz ich analizy można dokonać próby określenia kierunków rozwoju społeczeństwa informacyjnego na badanym terenie. Powinien się on opierać na kierunkach działań na rzecz ludzi (obszar człowiek) oraz podmiotów gospodarczych (obszar państwo). Miałoby to na celu przyspieszenie rozwoju kapitału intelektualnego i społecznego oraz wzrost efektywności, innowacyjności i konkurencyjności firm oraz ułatwienie komunikacji i współpracy dzięki wykorzystaniu właśnie technologii informacyjnych i komunikacyjnych.

Można byłoby to osiągnąć poprzez dalsze kształtowanie społeczeństwa, które potrafiłoby wykorzystywać postęp technologiczny do poprawy jakości swojego życia, społeczeństwa innowacyjnego, wykorzystującego nadarzające się okazje do osiągnięcia sukcesów. Aktywni mieszkańcy uczestniczyliby w życiu gospodarczym i społecznym swojego miasta i regionu.

\section{Literatura}

e-Polska - Plan działań na rzecz społeczeństwa informacyjnego w Polsce na lata 2001-2006, 2001, Ministerstwo Łączności, Warszawa

Goban-Klas T., 1999, Media i komunikowanie masowe. Teorie $i$ analizy prasy, radia, telewizji i Internetu, PWN, Warszawa-Kraków

Goban-Klas T., Sienkiewicz P., 1999, Społeczeństwo informacyjne. Szanse, zagrożenia, wyzwania, Kraków

Kropiwnicki, 2001, Budowa cywilizacji informacyjnej jako filar dtugookresowej strategii dla Polski do roku 2025, [w:] T. Zasępa (red.), Internet. Fenomen społeczeństwa informacyjnego, Edycja Świętego Pawła, Częstochowa

Poskrobski B. (red.), 2001, Przedsiębiorstwo w okresie ksztaltowania zrównoważonego rozwoju, Wydawnictwo Politechniki Białostockiej, Białystok

Szczepański K., 1970, Elementarne pojęcia socjologii, PWN, Warszawa

Proponowane kierunki rozwoju społeczeństwa informacyjnego w Polsce do 2020 roku, 2004, Ministerstwo Nauki i Informatyzacji, Warszawa

Uchwała Senatu Rzeczypospolitej Polskiej z dnia 16 stycznia 2003 r. w sprawie niezbędnych działań mających na celu przygotowanie Polski do globalnego społeczeństwa informacyjnego, 2003, Monitor Polski, nr 6, poz. 74

Rozwój telekomunikacji i poczty $w$ dobie spoleczeństwa informacyjnego, 2004, Ministerstwo Infrastruktury, Warszawa

Spoleczeństwo informacyjne warunkiem i efektem budowania GOW w Polsce, 2004, Ministerstwo Nauki i Informatyzacji, Warszawa

Stroińska E., 2004, Społeczeństwo informacyjne a hipoteza o „końcu pracy”, [w:] L. Haber (red.), Społeczeństwo informacyjne. Wizja czy rzeczywistość?, T. II, Wyd. AGH, Kraków, s. 61-74

Strategia rozwoju spoleczeństwa informacyjnego w Polsce do 2013 r., 2006, Ministerstwo Spraw Wewnętrznych i Administracji, Warszawa, s. 4

Toffler A., 1996, Budowa nowej cywilizacji. Polityka trzeciej fali. Wydawnictwo Zysk i Spółka, Warszawa

Wilk W., 2001, Polska wobec wyzwań spoteczeństwa informacyjnego, [w:] T. Zasępa (red.), Internet. Fenomen społeczeństwa informacyjnego, Edycja Świętego Pawła, Częstochowa, s. 152-153 


\section{Industry and services development in Jelcz-Laskowice as a factor in informative society creation in the town}

The community of Jelcz-Laskowice has been transformed from industrial society into informative society due to the rapid growth of electronic information and using communication and information technologies. This change is a very important element which ensures the quick and balanced socioeconomic development of the town.

The aim of this research is to show the process of formation and functioning of the informative society in Jelcz-Laskowice. Some factors which have influenced formation and development of the informative society in the town are analyzed in this study. The author also characterizes the process of community transition from industrial to informative society.

The citizens of Jelcz-Laskowice frequently use information technology not only at work, but also in private life.

Having analyzed the society of Jelcz-Laskowice as an informative society, to study its formation the author used some selected rates. The research mainly focuses on the questions of accessing and using such technologies.

Mgr inż. Joanna Bałach-Frankiewicz

Uniwersytet Wrocławski

Instytut Geografii i Rozwoju Regionalnego

e-mail: balach@wp.pl 